\title{
Desalination and Alternative Water-Shortage Mitigation Options in Israel: A Comparative Cost Analysis
}

\author{
Nir Becker ${ }^{1}$, Doron Lavee ${ }^{1}$, David Katz ${ }^{2}$ \\ ${ }^{1}$ Department of Economics and Management, Tel-Hai College, Upper Galilee, Israel \\ ${ }^{2}$ Recanati School of Management and Porter School of Environmental Studies, Tel Aviv University, Israel \\ E-mail: nbecker@telhai.ac.il,doron@pareto.co.il,katzdl@post.tau.ac.il \\ Received September 18, 2010; revised October 20, 2010; accepted November 21, 2010
}

\begin{abstract}
Costs for seawater desalination have dropped significantly over the past decade due to technological advances. This has increased the attractiveness of desalination to policy-makers as a means to address water supply shortages. Israel, a country that faces chronic water scarcity, is in the process of developing widescale desalination capacity that is projected to supply all of the nation's domestic water use within a few years. Two issues are often neglected, however, by policy-makers pursuing desalination. The first is that seawater desalination is associated with a number of external costs, consideration of which may influence the optimal scale and timing of desalination implementation. The second is that alternative measures for managing water scarcity, including conservation techniques, are often more cost-efficient. This study estimates the full cost of desalination in Israel, including externalities, and then compares this to the costs of several alternative options for addressing water scarcity, including both demand management and supply augmentation measures. We find that desalination, despite being the primary policy option pursued by Israel, is among the least cost-efficient of all the alternatives considered, even without taking into account the externalities involved.
\end{abstract}

Keywords: Cost-effectiveness Analysis, Desalination, Israel, Water Policy

\section{Introduction}

Annual water consumption in Israel has outstripped the nation's renewable freshwater supply since major water supply systems were put in place in the 1960s. To supply growing water demand, Israel has looked towards alternative sources, including use of reclaimed wastewater, treatment of brackish water, and more recently, large investments in seawater desalination. Israel's approach to managing water scarcity has focused largely on supply management rather than demand management. Supply management concentrates on developing additional or alternative sources of water supply, including production of water from marginal sources such as wastewater or seawater or through import of water from other countries. Demand management solutions focus on reducing demand for water, and may include price adjustments, increasing the price of water, introducing trade in water allotments (totaling the available amount of renewable water supply), etc. [1-3].

Two main arguments have been raised in support of supply side management which has led policy makers in
Israel to develop plans to increase the amount of water produced beyond the natural renewable level $[4,5]$ :

1) Producing additional water can reduce costs associated with the uncertainty of water supply.

2) Water can be thought of as a "bridge to peace." Since water is a scarce transboundary resource in the Middle East, a greater supply of available water can reduce political tensions [6,7].

In recent years, seawater desalination has increasingly been viewed as a basic instrument to solve problems of water scarcity. This is true not only in Israel but in other parts of the world [8-10]. Prior to 2006, Israel produced only about 30 million cubic meters (MCM) annually by desalination (out of a total of more than 1500 MCM consumed). However, in 2006 a desalination plant in the city of Ashkelon began operation, producing over 100 MCM each year. As of 2010, Israel has three large seawater desalination plants, and a total desalination capacity of nearly $280 \mathrm{MCM}$, over a third of municipal water consumption. The national plan is to increase desalination capacity to between 600-1,000 MCM per year with- 
in the next ten years. This is projected to account for $100 \%$ of the forecasted municipal water demand in 2020 .

In the past, desalination was a relatively expensive solution when compared to conventional water production alternatives, and was thus implemented on a limited scale in Israel in isolated areas far from existing infrastructure. However, the costs of water supply in recent years have risen as water shortage necessitated production from marginal water sources, and at the same time the cost of desalination has declined dramatically, from roughly $\$ 2.50$ per cubic meter in the 1970 s to roughly $\$ 0.50$ by 2003 [11-14]. In addition to producing water for direct consumption, by diluting desalinated water with water from the regular water supply system, it is possible to increase the total amount of water available for both drinking and for agricultural uses [15,16].

Desalination, however, has certain significant negative environmental impacts that add to the overall cost of desalination beyond direct production costs [17-19]. An analysis which internalizes these externalities may reveal more efficient means to deal with water supply shortages, such as price adjustments, investing in water saving equipment, increasing water reuse, and reallocation of water between different uses. In a country such as Israel suffering from significant water supply shortages, this argument is of particular significance.

The purpose of this paper is to quantify some of the externalities associated with desalination and then use the results to compare the true costs of desalination with other policy options available to address water shortages. Specifically, six other alternatives are considered, two supply augmentation options-expanding wastewater reclamation and reuse in agriculture and reducing evaporation losses from wastewater reservoirs-and four demand management options-investment in faucet filters that reduce household consumption, price increases for water use by the agricultural sector, changing plant types and irrigation techniques in public parks and gardens, and installation of greywater systems.

The paper continues as follows. Section 2 provides background regarding water policy in Israel. Section 3 reviews the literature on desalination, focusing on studies which consider its external impacts. Section 4 attempts to quantify these impacts and assign them dollar values, while Section 5 describes the costs associated with the four other proposed alternatives for mitigating the water shortage problem. Section 6 summarizes and concludes the findings.

\section{Background: Water Policy in Israel}

\subsection{Physical Setting}

The State of Israel has a semi-arid climate with signifi- cant fluctuations in annual precipitation. It suffers intermittently from series of very dry years during which annual evapo-transpiration may be greater than annual precipitation. Israel's water potential is derived from four types of sources: groundwater or aquifers, natural surface reservoirs, storm run-off, and recycled domestic and industrial effluent. Total annual renewable water resources are estimated at roughly 1,400 MCM, most of which are derived from three major sources-the Coastal and Mountain Aquifers, and Lake Kinneret (the Sea of Galilee), the annual operational volume which are roughly 280 MCM, 330 MCM, and 400 MCM, respectively. Total annual renewable supply is highly variable and has been declining, possibly due to global warming [20].

The availability of water from these sources is limited by the annual recharge rate and by the need to maintain a minimal water table level. Withdrawal of water in excess of the recharge rate, i.e., allowing the water level to fall below the designated minimum levels, would lead to the intrusion of brines and deterioration of water quality and deterioration of aquatic ecosystems. Despite the risk of water quality deterioration, over-extraction of freshwater has continued frequently for more than 30 years.

Most of Israel's water sources are shared with its neighbors. Lake Kinneret gets most of its water supply from the Upper Jordan River, the headwaters of which originate in Israel, the Golan Heights, and Lebanon. The outflow from the Sea of Galilee to the Lower Jordan River currently constitutes the border between Israel and Jordan and further downstream between the West Bank and Jordan. The Mountain Aquifer underlies both Israel and the West Bank, providing nearly all of West Bank's freshwater supply and roughly one-third of Israel's natural renewable freshwater supply. The southernmost part of Israel's Coastal Aquifer also extends to the Gaza Strip, although the interaction between the two parts is limited.

\subsection{Historical Water Management in Israel}

Water policy in Israel may broadly be divided into three periods: 1) 1948-1967: development of local water sources and institutional organization; 2) 1967-1990: expansion of agriculture based on increased water supply; 3) 1990s-present: weighing demand versus supply management [20]. Following the establishment of the state of Israel in 1948, the government invested heavily in developing water infrastructure as well as institutions for national level water management. The most important institutional decision was the enactment of the Water Law in 1959 which regulated water production and allocation. This law nationalized almost all water sources in the country and established a Water Commission to allocate rights to water usage to applicants on an annual 
basis. Given the political power structure and ideological leanings of Israeli leaders in this period, priority was given to agricultural uses of water, which were subsidized relative to alternative uses. In terms of water infrastructure, in the mid-1960s Israel finished construction of a National Water Carrier (NWC), which conveys water from Lake Kinnert in the north to the central and southern parts of the country. Completion of the NWC enabled integration of all three primary basins, thus allowing full allocation of all of the country's freshwater resources [21].

Despite completion of an integrated national water conveyance system, a considerable gap between the total demand for water and the existing supply persisted. The two main features of the national water policy remained unchanged: allocation of a considerable amount of water for agricultural uses, and an agreement among decision-makers not to use prices as an incentive for water demand management in agriculture. As demand grew in non-agricultural sectors, especially in the municipal sector, agriculture served as a "water bank" of the state, bearing the brunt of cuts in water-lean years. This was unacceptable to the agricultural sector, and, in response, a strong lobby emerged, pressuring the government to allocate significant resources for developing new water supply sources [22,23]; this, despite decreasing economic and ideological importance of agriculture in the country.

Israeli water policy has continually sought technical fixes for its stressed water sector. Israeli agriculture pioneered drip-irrigation techniques, which were widely implemented in the $1960 \mathrm{~s}$ and $1970 \mathrm{~s}$. Similarly, it also invested in development of salt-tolerant crops. While these techniques led to improved yields and increased efficiency per unit of water in agriculture, they did not lead to reduced overall agricultural water demand. Several supply augmentation techniques, such as, cloudseeding and treatment of brackish water, were actively pursued, but produced only marginal increases in overall supplies. Prior to 2005, desalination was implemented on a limited scale, as costs were deemed prohibitive. One policy that did lead to significant increases in supply of water available for the agricultural sector was treatment of wastewater. Israel drafted the world's first set of standards for wastewater reuse in 1953, and effluent recycling emerged as a central element of Israeli water policy. At present, 91\% of all municipal sewage in Israel is treated, $73 \%$ of which is then reused in agriculture, making it the world's leader in terms of recycling of treated wastewater. Treated wastewater currently contributes roughly one-fifth of Israel's total water supply and over one third of agricultural water (see Figure 1).

\subsection{Modern Water Policy in Israel}

\subsubsection{Increasing Demand, Increasingly Unreliable Supply}

By the mid-1990s, several additional sources of water demand had stressed the existing management system, including increased municipal water demand, increased allocations of shared water with Arab neighbors, as dictated by peace agreements, and increased demands for instream flows for environmental purposes. Significant population growth, both natural and due to immigration,

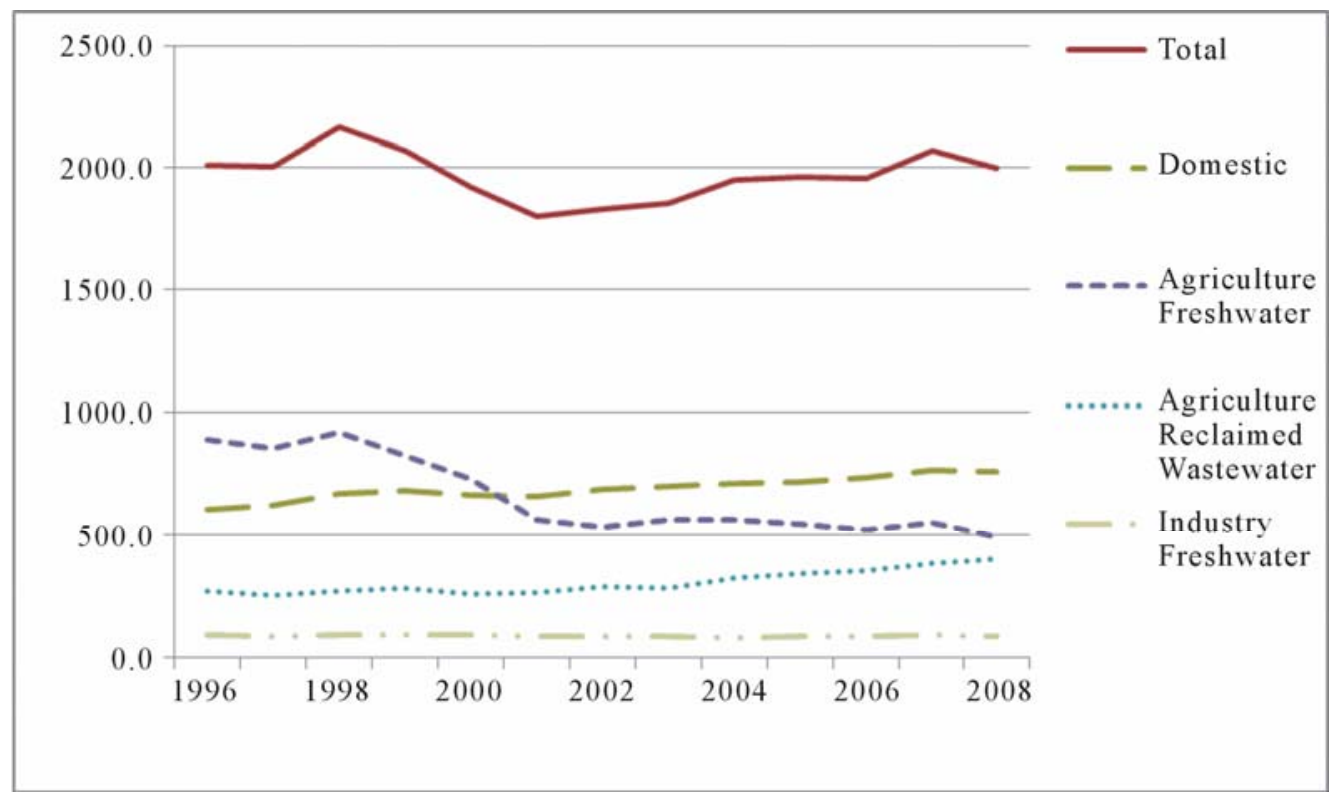

Figure 1. Water consumption by type in israel 1996-2008 (in MCM), source: IWA, 2010. 
combined with rising standards of living led to a steady increase in domestic water consumption. By 2001, domestic uses replaced agriculture as the primary consumer of freshwater (see Figure 1). The signing of peace agreements with neighbors entailed sharing more water with its neighbors (50 MCM to Jordan annually and an additional 28.6 MCM to the Palestinian Authority, with more expected in a final status agreement). Given that freshwater was fully allocated, these increases came largely at the expense of agriculture.

With Israel's historical water policy resulting in the dewatering of the country's coastal streams, wetlands, and other national treasures like the Dead Sea, in the 1990s environmental groups initiated campaigns to allocate instream flow to restore and maintain the nation's aquatic ecosystems. These efforts were eventually successful in amending the National Water Law to include environmental flows as legitimate beneficial uses (Amendment 19, 2004) and in securing the promise of 50 MCM for restoration purposes. The campaign also highlighted the tradeoffs between competing extractive and instream uses, including the link between over-extraction and water quality. Environmentalists, however, found some common ground with farmers, stressing the role of agriculture in protecting rapidly diminishing open spaces. Thus, despite the conservationist theme of the environmental campaigns, they, at least in part, contributed to a policy orientation focused on supply augmentation.

While demand was rising throughout the 1990s and 2000s, supply was becoming less reliable. The region experienced multiple multiyear droughts, and the country drew down its reservoirs, both ground and surface water, to historically low levels. As a result of over-withdrawals, combined with lax land-use policies, many sources of groundwater in the coastal aquifer became contaminated and unusable. Furthermore, a series of studies indicated that, as a result of climatic change, future annual rainfall in the region could be up to $30 \%$ less than in the past, with more frequent drought periods, and an increase in evaporation [24].

\subsubsection{Supply Management-Banking on Desalination}

Given recurring shortages, water managers and policymakers considered a range of demand and supply management options. Among the primary demand management options considered were awareness raising campaigns, price increases, reduction in allocations to agriculture, and installation of greywater systems. Supply management options primarily focused on desalination and importation of water from abroad. In the end, while some demand management policies were eventually initiated, the core of recent Israeli water policy has been built primarily around desalination.
The Israeli Water Authority (IWA) (the successor to the Water Commission) introduced several public campaigns to conserve water. These were considered as short-term measures, not long-term solutions. In 2009, the IWA announced plans to raise water prices for municipal users, including a significant rise in the tariff on marginal consumption (the third of a three block tariff). Initial experience from the marginal price reform, popularly dubbed the "drought tax", indicated that it was effective in lowering consumption patterns. Following implementation of the tax, consumption fell by nearly $20 \%$ from the previous year [25], although it is difficult to separate the effects of the tax from those of awareness raising campaigns. Although deemed necessary for limiting consumption by both the Head of the IWA and by an outside advisory panel, price reform encountered significant popular and political resistance by politicians and by the State Comptroller, who claimed that such reforms placed an unfair burden on poorer populations (e.g. [26,27]). In the face of such opposition, the marginal price increases were suspended in early 2010.

Cuts to agricultural freshwater supplies were introduced in the 2000s, however, farmers had been guaranteed a minimum of 500 MCM of freshwater, and water managers faced stiff opposition to reducing below this amount. Greywater systems were never implemented at a large scale and currently are not allowed due to regulatory opposition from the Ministry of Health. The IWA has also expressed reservations about greywater systems claiming that they would increase the concentration of pollutants in sewage, raising treatment costs and reducing the amount of treated sewage available for agriculture (e.g., [28]).

Plans to import water from Turkey were discussed at the highest levels of government, but were eventually abandoned for a combination of cost and security reasons. Instead, decision-makers decided to pursue wide-scale development of desalination. In the past, high costs limited the scope of desalination to reverse osmosis (RO) facilities in remote agricultural communities and at the Red Sea resort town of Eilat, where no viable alternative water sources exist. Today, the combination of modern membrane technologies, reduced energy consumption, and the economies of scale associated with mass production yields very-high-quality drinking water production at Israel's Mediterranean coast at a cost of less than $\$ 0.60$ per CM [4,7]. These new economic realities led to a 2002 government decision to construct five new RO desalination plants over the coming years with an expected capacity of between 600-1000 MCM. As noted above, the first such plant began full operations in 2006 and currently (2010), desalination provides for roughly 280 MCM or over one third of national domestic water 
consumption. Despite reservations by the Ministry of Finance regarding costs, the government has promoted desalination as the primary solution to the nation's chronic water scarcity. ${ }^{1}$ To wit, in 2010, an official IWA campaign slogan explicitly called on people to conserve water for another three years until such time as installed desalination capacity is expected to supply enough water to solve national water scarcity [29].

\section{Direct Costs of Desalination: A Literature Review}

Seawater desalination was first implemented in the 1950s. Currently, there are about 12,000 desalination plants in the world, producing $0.02 \%$ of global water consumption [30]. Most of these plants are located in the Middle East. The economic literature on seawater desalination focuses mainly on the costs of desalination [14,31,32] and on comparisons of alternative desalination technologies [33, 34]. More specifically, numerous papers compare the costs of seawater desalination to those of more conventional water production methods. Several studies have found seawater desalination to be an inferior solution compared to alternatives such as conservation or reallocation $[10,35,36]$. Sabol [32], for example, mentions that despite the drop in the costs of desalination with Reverse Osmosis (RO) technologies by $80 \%$ over the last 25 years, it is still more expensive than conventional water production methods. According to Afgan et al. [37] and Daniels and Daniels [31], seawater desalination is on average more than twice as expensive as groundwater extraction. Downward and Taylor [38] indicated that desalination was a cheaper option than large-scale interbasin transfers being considered in Spain. Tsur and Zemel [39] examined how the demand for water on one hand, and water supply shortage on the other, determine development processes of desalination technologies and the optimal timing of their implementation.

In recent years, a growing body of literature is concerned with the environmental impacts of seawater desalination. Pitzer [35], for instance, studied the issue of the residual salt concentration and its impact on marine life when dumped back to the sea. Sadiq [40] examined the impact of the desalination plant in Ras Tanajib, Saudi Arabia, on marine life in the vicinity of the plant and found significant remainders of metals along the shore. Azis et al. [18] looked at the impact of the desalination plant at Al Jubail, Saudi Arabia on both marine life and water quality. Likewise, they found significant impacts

${ }^{1}$ It should be noted that government positions have not been unanimous in favor of support for wide-spread desalination. The Ministry of Finance has routinely expressed reservations about the costs and scale of desalination facilities. and suggested several alternative solutions. Altayaran and Madany [17] analyzed the effect of the desalination plant in Sitra, Bahrain on water quality in the nearby area. El Fadel and Alameddine [9] compared desalination to conventional water production in environmental and political contexts. Glenn [41] analyzed the impact of the desalination plant in Yuma, Arizona on the wetland area in the delta of the Colorado River in Sonora, Mexico, focusing on its long-run effects. Yuhas and Daniels [10] looked at the environmental impact of the desalination plant in Tampa Bay, Florida, and found significant causes for concern. They concluded that at the current technology level and given the significant uncertainty concerning environmental impacts, desalination should be avoided when possible, while other water management means such as groundwater use, water recycling, water saving technologies and water price increases are preferable.

Many studies have commented on the need to conduct a full life cycle energy assessment, including environmental costs, when considering different water supply alternatives (e.g., [38,42]). Few, however, actually attempt to quantify environmental costs. Stokes and Horvath [42] compare desalination, importation of outof-state water importation, and water recycling options and find that desalination is associated with significantly greater energy demand, and associated air pollution costs, than the other two alternatives. A certain limitation of the study, however, is that sources on which the monetary values attributed to the different pollutants are based are somewhat dated (from the early 1990's). Nisan and Benzarti [43] analyze different types of desalination plants (making use of different types of fuels), taking into account both the direct energy costs and the external costs associated with emissions. They conclude that when externalities are taken into account, systems based on nuclear technology are economically superior to fossil-fuel based plants. Karagiannis and Soldatos [11,44] also consider the externalities of desalination, focusing on greenhouse gas (GHG) emissions. In the context of the Greek islands, they investigate under what conditions it would be economically worthwhile to invest in desalination plants based on renewable energies rather plants using fossil-fuels. They find that such an investment may indeed be warranted under reasonable assumptions regarding the environmental cost of $\mathrm{CO}_{2}$ emissions. They do not consider other air pollution emissions or other types of externalities.

Only by comparing the full costs of different alternatives will it be possible to determine the optimal timing of implementing a given technology and its required amount. This paper evaluates desalination externalities 
associated with several types of air pollution as well as the use of coastal land.

\section{The External Costs of Desalination in Israel}

Concerning the direct costs of desalination, Dreizin [5] reports an estimated cost of 52.2 cents per CM for the last tender carried out in Israel. This is one of the lowest cost estimates found in the literature and doubts are currently emerging whether the winning company will indeed be able to supply the water at this price. Nevertheless, for the purpose of the estimations in this paper we will use this price (which is equivalent to roughly 2 shekels (NIS) per CM). ${ }^{2}$ In addition to the direct production costs, however, external costs must be added to gauge the full societal costs of desalination.

Seawater desalination is associated with three major negative environmental impacts: air pollution and greenhouse gas emissions, expropriation and use of land along coastal areas, and damages to marine life due to the pumping of seawater into the plant and the discharge of residual salts and minerals. We will discuss each of these impacts separately.

\subsection{The Costs of Air Pollution and Greenhouse Gas Emissions}

Desalination plants consume significant amounts of energy. Indeed, 30 to 50 percent of the total cost of the desalination process is associated with energy consumption [45]. Moreover, the plants must operate on a continuous basis, hence the potential for using alternative energy sources for this purpose is very limited, and the plants must rely on conventional fossil-fuel power.

Desalination of 1 cubic meter of water currently requires between 3.7 and 4.5 kilowatt hours ( $\mathrm{kWh}$ ) of electricity. For this paper we assumed an average energy consumption of $4.25 \mathrm{kWh}$ per cubic meter. In evaluating external costs representing damages caused by the major pollutants released during energy generation from conventional sources, we focus on four primary pollutants: Particulate Matter (PM), $\mathrm{NO}_{\mathrm{X}}, \mathrm{SO}_{2}$ (all of which are associated with human health risks) and $\mathrm{CO}_{2}$, (the primary

\footnotetext{
${ }^{2}$ As of 15 October, 2010, 1 US\$ $=3.68$ NIS. At the time of Dreizen's estimate (2007) the exchange rate was roughly 1 US\$ $=4$ NIS.

${ }^{3}$ It should be noted that calculating an externality based on abatement costs is an imperfect measure, as it is not based on actual damages. Rather it is based on the cost of meeting abatement requirements that are thought to be insufficient to stabilize global greenhouse gas emissions. It is clearly an underestimate of the abatement costs necessary to stabilize climatic change, and, as such, it is also likely an underestimate of true damages.
}

greenhouse gas). To assess these costs we used estimates from the Israeli Ministry for Environmental Protection (MEP) [46].

MEP cost estimates for $\mathrm{NO}_{\mathrm{X}}, \mathrm{SO}_{2}$, and $\mathrm{PM}_{10}$ were based on the results of the European CASES project (Cost Assessment for Sustainable Energy Systems). This project used the methodology developed within the Extern-E project for the evaluation of the externalities of energy generation [47], and presents pollution costs on an emissions per ton basis for each country in the European Union as well as neighboring countries (North African and Eastern European countries). These costs were estimated using simulations taking into account climate, population density, and epidemiological studies linking pollutant concentrations and morbidity and mortality rates. Using this dataset, MOE [46] estimated adjusted pollution costs for Israel on the basis of two parameters: population density in the surrounding region (within a radius of several hundred kilometers), and national income (as measured by Gross Domestic Product (GDP) per capita).

MOE [46] estimates for $\mathrm{CO}_{2}$ are also based on the value provided by the CASES project. Values were determined both by an analysis of model simulations concerning the potential damages of global warming and an assessment of abatement costs of reducing $\mathrm{CO}_{2}$ emissions. ${ }^{3}$ The value arrived at by Extern-E, 19€/ton, was then adjusted to economic conditions in Israel on the basis of the ratio between GDP per capita in Israel and that in the European Union. Israel currently is not under an obligation to reduce greenhouse gas emissions, but will almost certainly be under such an obligation in any future global climate agreement, given its recent accession to the OECD. As such, these estimates are completely in the realm of feasible external costs. If and when an agreement should come into effect, the costs representing abatement would be direct costs, not external costs.

In order to calculate pollution costs per kWh of electricity generated, we use data on average emissions during electricity generation in Israel, as reported by the Israeli Electricity Company [48]. As can be seen in Table 1, the estimated environmental damage costs from air pollution due to desalination in Israel amount to over US\$0.13/CM. Given Israel's current desalination capacity of roughly 280 MCM of desalination per year, as of 2010, external costs due to air pollution alone are over \$36 million annually. Should the government follow through with planned capacity of $600 \mathrm{MCM} / \mathrm{year}$, this figure would rise to nearly $\$ 80$ million annually, and at a capacity of $750 \mathrm{MCM} / \mathrm{year}$, external costs from air pollution would rise to nearly US $\$ 100$ million 
Table 1. Air pollution externalities of desalination.

\begin{tabular}{ccccc}
\hline & $\begin{array}{c}\text { Pollution costs per ton } \\
\text { emitted } \\
(\mathbf{\$} / \mathbf{t o n})^{\mathbf{a}}\end{array}$ & $\begin{array}{c}\text { Average emissions during } \\
\text { electricity generation } \\
\text { (gram/kWh) }\end{array}$ & $\begin{array}{c}\text { Emission costs per kWh } \\
\text { generated } \\
\text { (cents/kWh) }\end{array}$ & $\begin{array}{c}\text { Emission costs per 1 CM } \\
\text { of desalinated water } \\
\text { (cents/CM) }\end{array}$ \\
\hline $\mathbf{S O}_{\mathbf{2}}$ & 6,468 & 1.6 & 1.03 & 4.40 \\
$\mathbf{N O}_{\mathbf{X}}$ & 3,746 & 1.7 & 0.64 & 2.71 \\
$\mathbf{P M}_{\mathbf{1 0}}$ & 9,232 & 0.05 & 0.05 & 0.20 \\
$\mathbf{C O}_{\mathbf{2}}$ & 19.39 & 707 & 1.37 & 5.83 \\
Total & & & & 13.13 \\
\hline
\end{tabular}

Source: MOE (2008), IEC (2010) and authors' calculations, ${ }^{\text {a }}$ Values in MOE (2008) were stated in $€$. They have been converted to $\$$ using an exchange rate of 1.3075 .

annually. ${ }^{4}$

\subsection{Use of Land along the Coastal Area}

Desalination plants in Israel are most often built along the coastline. Given that Israel is a densely populated country (over 340 persons per square $\mathrm{km}$ ), and that over half of the total population lives along the coastal strip, coastal land is highly valued. The alternative value, or opportunity cost, of those areas taken up by desalination plants should thus be taken into account in assessing the true cost of desalinated water. These areas are dedicated to desalination by government decree, and thus, the market alone does not account for these costs.

The external costs from land use by desalination plants are represented in Equation (1).

$$
C=\frac{(A V \times D P)}{Q}
$$

where:

$C=$ Cost per cubic meter of water produced

$A V=$ Average monetary value of coastline property per unit area

$D P=$ Area of relevant coastline appropriated by desalination plants

$Q=$ Quantity of desalinated water produced in cubic meters

\footnotetext{
${ }^{4} \mathrm{~A}$ future switch in Israel's fuel mix towards increased use of natural gas and less coal for electricity production would reduce GHG emissions, and thus lessen overall costs. (If all desalinated water was produced solely with natural gas, rather than the current fuel mix, which is roughly two-thirds coal and one third natural gas, estimated externalities from air pollution would decrease to 4.8 cents per cubic meter of water.) An international climate agreement requiring reductions in GHG emissions would, however, likely increase abatement costs, and thus also the calculated externality costs. While these two likely events would somewhat offset one another, in this paper we do not speculate as to what extent they might change the estimates of current damages.

${ }^{5}$ It should be noted that this estimate may be a conservative one, as it is less than the estimate of US\$0.06-0.10 given by FoEME [50]. This same report also provides a higher estimate of air pollution damages (US\$0.19/CM), although this is largely due to an assumed future carbon price of $30 € /$ ton.
}

A weighted average of the different values of the Israeli shorelines is provided in Kivun [49]. It revealed a maximum annual value of 190 NIS, or roughly US\$0.50 per square meter of shoreline. In Israel, desalination plants with production capacities of roughly 100 MCM each have taken up about 100 meters length of shoreline and 7 hectares of territory [4]. This produces an estimate of roughly US\$ 0.034 per CM. ${ }^{5}$ This represents another nearly US\$10 million annually for current desalination capacity, and over \$20 million for production capacity of $600 \mathrm{MCM}$, and nearly \$26 million for capacity of 750 $\mathrm{MCM} /$ year. While it is not necessary to locate desalination plants along the coastline, this has been the practice for those constructed thus far. Distancing the plants from the coastline would reduce (but not eliminate) externalities from land use, but would increase operating expenses.

\subsection{Damage to Marine Resources}

Environmental impacts of desalination have been long documented [50-53]. Marine life in the vicinity of a plant is impacted by its operations primarily due to both the discharge of salt residuals and the pumping of seawater into the plant $[14,19]$. Specific sources of risk include:

- High salt concentration of the residuals: $63 \mathrm{~K} \mathrm{ppm}$ relative to $35 \mathrm{~K}$ ppm, which is the natural level of salt concentration in the seawater.

- Higher temperature at the discharge site relative to the natural temperature of the sea.

- Desalination residuals characterized by high turbidity rates compared to the natural seawater turbidity rate.

- Low oxygen level of the residuals, compared to the natural seawater level.

- Dumping of chemicals used in the pre-treatment stage.

- Dumping of metals and other inorganic materials which accumulate during the desalination process.

All of these impacts may be harmful to marine life. 
For example, metals can poison reproduction areas for some fish species, high chloride concentration can cause high sedimentation levels which in turn may have a negative impact on Phytoplankton beds, and higher temperatures can have a negative impact on the reproduction capability of some marine organisms. Relatively little quantitative research on actual impacts of desalination exists, but it does appear that discharges on the marine and coastal environment vary greatly based on site location [54]. In Israel, impacts from brine discharge have been noted, but not yet quantified [55]. Unfortunately, we are unaware of any study that has tried to estimate the dollar value of marine damages. Studies based on the Contingent Valuation method or on production functions may be appropriate here, but for our present purposes we will safely assume that our estimates for the total negative externalities of desalination constitute only a lower bound, as they do not incorporate damages to marine resources.

\subsection{Positive Externalities Associated with Desalination}

Desalination of the water (both brackish and seawater) has a potential benefit of reducing salinity in the water system. For example, the level of salinity in desalinated water is roughly $100 \mathrm{mg} \mathrm{Cl} / \mathrm{L}$, while the level of salinity in freshwater from natural sources in Israel is roughly $250 \mathrm{mg} \mathrm{Cl} / \mathrm{L}$. The decline in salinity level contributes in three aspects: prevention of decline in crop yield, improved aquifer water quality, and savings on household and industrial electrical equipment and sanitary systems [56].

With respect to the first issue, prevention of decline in crop yield, when irrigation is done with a high-salinity level of water, salts accumulate in the soil and damage crop growth over time. In order to conserve the land for future agricultural uses, the soils must be flushed periodically. The amount of water required to flush the land depends on a number of parameters: crop type, soil type, climate, rainfall, and salinity level of the water used in irrigation. At this point we cannot measure the benefits associated with this component. It requires further, more focused study.

With respect to the second issue, desalinated water will also reduce salinity levels of aquifers, Salinity levels in Israel have been rising rapidly over the years, and if no policy changes are made, they are expected to reach $400 \mathrm{mg} \mathrm{Cl} / \mathrm{L}$ within about 10 years, in which case it will not be possible to use the water without desalination. Introducing higher standards for treated wastewater (that is, requiring two levels of desalination) will delay this development.
With respect to the third component, reduced damages to electrical appliances and sanitary systems, high salinity in water leads to increased formation of scale, which, in turn, causes damage to both domestic appliances and industrial equipment. For this too, we have little data on economic value. Lavee, however, provided a rough preliminary estimate of all three components of about $0.1 \$$ per $1 \mathrm{CM}[56]$.

\subsection{Summary of True Cost of Desalinated Water}

Summing the estimates for air pollution and land use externalities gives a figure of roughly US\$0.065 per CM of desalinated water. Adding this to the direct costs of production gives a figure of US\$0.585 per CM. Given the absence of marine damage valuation as well as some positive externalities mentioned in 4.4 , this estimate may be biased upward or downward by a few cents.

\section{Alternatives for Mitigating Water-Shortage}

In this section we examine alternatives for mitigating water-shortage, including both supply and demand side management options. With respect to the supply side, we examine whether the potential exists to increase water supply in a cheaper and more efficient manner (compared to desalination), at least in the short-run. We evaluate two such policies: increased wastewater reuse in agriculture and reducing evaporation from treated wastewater reservoirs. On the demand side, we examine four potential policies: reducing water consumption by the agricultural sector by raising prices, reducing domestic demand by investing in water saving faucet filters (henceforth "Water Savers"), installing grey water infrastructure, and changing plants and irrigation techniques in parks and both public and private gardens.

Our comparative analysis of the alternatives is based on the criterion of cost-effectiveness. That is, the preferred alternative is the one which produces an additional cubic meter (or saves one) at the lowest cost.

\subsection{Increasing Wastewater Reuse in Agriculture}

As mentioned earlier, Israel is already utilizes over $70 \%$ of the treated sewage as a source of irrigation water. However, opportunities exist to expand the quantity treated and improve the quality of treated water, increasing its potential for reuse.

This solution may be associated with several key advantages:

1) Relatively low cost (as described below).

2) A double-dividend element of both providing addi- 
tional water and removing pollutants from the environment, given that without treatment, wastewater pollution reaches streams and groundwater.

The quantity of urban wastewater is positively correlated with the size of the urban population and its income level. Thus, using treated wastewater to increase water supply may help address future increases in water demand for agricultural purposes, or alternatively may allow less reliance on freshwater sources.

By 2015, available wastewater supply in Israel is forecasted to reach about 515 MCM per year [56]. Currently, the agricultural sector uses just under $400 \mathrm{MCM}$ of treated wastewater annually. This means that if steps are taken to ensure treatment and reuse of the additional amount of available wastewater, demand for freshwater may be reduced by almost 116 MCM annually, equal to about $16 \%$ of the planned desalination capacity. In addition, this type of solution may be implemented faster than desalination.

In order to analyze the feasibility and efficiency of increasing reuse of domestic wastewater in agriculture, we must assess the following:

1) The cost of treatment required to bring the wastewater to a level suitable for reuse in agriculture.

2) The cost of delivering the water from the treatment plant to the point of use.

3) The costs associated with the removal of wastewater from rivers and groundwater (which would need to be carried out regardless of potential reuse).

4) The environmental benefit of such a policy.

It is thus necessary to differentiate between the costs associated with the basic treatment of wastewater for pollution prevention purposes, which must be borne by the national economy regardless of potential reuse, and those specifically required to allow use of treated wastewater in agriculture. The true costs of increased use of recycled wastewater in agriculture are the additional costs required to upgrade water quality level beyond that required for pollution prevention, as well as the costs of conveying the water from the treatment plants to the fields where they are to be used (minus the costs of conveying the treated wastewater to discharge in streams or the sea, and any environmental damage from doing so). Lavee [56] points out that this additional cost associated with transporting the wastewater to agriculture use, subtracting the cost-savings achieved by replacing the need to deliver the treated wastewater to the rivers or the sea, is about 1 NIS, or US\$0.26, per CM.

Lavee [56] carried out a detailed analysis of 80 treatment plants and concluded that over US\$240 million must be invested in order to upgrade the plants to stan-

${ }^{6}$ A Calculated using a 5\% cost of capital and a 20 year return on investment. dards that were adopted as policy goals by the Ministry of Environmental Protection in 2005. Additionally, annual operation and maintenance costs are estimated at \$35 million. Accordingly, the additional cost of raising treatment standards to allow increased use of treated wastewater in agriculture is estimated at US\$0.185 NIS per CM. Including the additional costs of conveying the treated wastewater to the irrigation fields, the total cost of increasing wastewater reuse in agriculture thus reaches US\$0.45 per CM. ${ }^{6}$

\subsection{Reducing Evaporation from Wastewater Reservoirs}

Because of high temperatures and an extended dry season in Israel (May through September), a substantial percentage of available water evaporates before it is utilized. Thus, reducing water losses due to evaporation from exposed surface water reservoirs represents another possible option for conservation. Israel has a limited number of freshwater reservoirs, but does have numerous wastewater reservoirs. FoEME [57] estimates that 12$15 \%$ of water from open reservoirs is lost to evaporation. Furthermore, they estimate that covering these reservoirs would reduce evaporation by 60-75\%. Applying the more conservative of both these estimates to the projected figure of $515 \mathrm{MCM}$ of wastewater produced per year, gives an estimate of $37 \mathrm{MCM} /$ year that could be saved by covering the reservoirs.

Several methods for reducing such losses exist, ranging from coagulating powders to simple plastic or material covers to covering with solar panels. At this stage, only the powders and plastic and material covers have been proven to be technologically and economically feasible. FOEME estimates that current methods for covering reservoirs would cost roughly US\$12-15 per hectare per year, or less than US\$0.01 per CM conserved.

Several problems exist with implementing limiting evaporation losses from reservoirs. From a technical perspective, there are problems with covering of reservoirs, for instance, including development of algae on the interior of the coverings and the possibility of coverings blowing away or becoming detached. Furthermore, covering reservoirs also involves a loss of habitat and water for wildlife. The costs of these losses of ecological services are not included in the estimates in this study. These caveats, notwithstanding, the extremely low per unit cost of water makes this an option that should be seriously considered in national water policy.

\subsection{Investing in Water Savers}

Turning to demand management, one option for reducing 
municipal demand is to invest in Water Savers. Currently, urban water consumption in Israel is estimated at roughly $760 \mathrm{MCM}$ annually. Investing in water-saving equipment may reduce total urban consumption by up to $25 \%$ [ 58 , 59]. The average cost of such equipment is estimated at US\$80 per household and its average lifetime is about 3 years [59]. An average household consumes about 250 CM annually, such that over $60 \mathrm{CM}$ would be saved per household. Assuming a 5\% discount rate, such an investment would amount to US\$0.45 CM.

At a national level, a 25\% reduction in urban consumption would amount to 190 MCM in water savings annually, or nearly double the production capacity of a large-scale desalination plant, at a cost that is less than two-thirds the cost of desalination. The government announced intentions to implement a policy that would distribute some water-saving faucet fixtures to the population in the past and is only beginning to implement this in late 2010; a full five years after the first desalination plant began production.

\subsection{Increasing Price of Water in the Agricul- tural Sector}

Another alternative for demand management is reducing agricultural water consumption. In order to compare this alternative to desalination, we will assume that a planned additional 320 MCM of desalinated water (bringing total desalination capacity to $600 \mathrm{MCM}$, the lower range of suggested future capacity) will be taken away from the agricultural sector (without providing any replacement water) and analyze the impact this will have on the sector. A welfare analysis for the agricultural sector is presented in Figure 2.

Although water is allocated administratively in Israel, a majority of the farmers do not fully utilize their allocations, indicated that water is actually a price-rationed good [60]. Average agricultural water consumption over the past decade is estimated at about 570 MCM per year. In order to estimate the effect of a potential price increase on the agricultural sector we need to first estimate its water demand curve. This was done by estimating the value of the marginal product of the 45 crops grown in Israel, per CM [3]. The marginal product values were then listed in descending order so as to generate a demand function for water. Figure 2 presents the results for a semi-logarithmic function which was found to have the best fit for functional form (the figure is based on Equation 2).

$$
\begin{aligned}
& p=16.11-2.3941 n(w) \\
& R^{2}=0.88
\end{aligned}
$$

where:
$\mathrm{P}=$ Price of water, in NIS.

$\mathrm{W}=$ Total amount of water used, in MCM.

The average price paid for water by farmers in Israel is estimated at 1.39 NIS (roughly \$0.38) per CM. The average cost of water production from conventional sources is estimated at 1.79 NIS (roughly \$0.48) per CM. Multiplying the difference by total agricultural water consumption (570 MCM), we estimate the total water subsidy in Israel at over \$61 million annually. Since the increased profitability to farmers is estimated at \$46 million (change in consumer surplus between 1.79 and 1.39 NIS per CM) NIS annually, the net loss of the subsidy is estimated at $\$ 15$ million per year.

If we reduce the amount of water allocated to the farmers to 250 MCM (average agricultural consumption of 570 MCM minus proposed additional desalination capacity of $320 \mathrm{MCM}$ ), we find that the market price which clears the market for this amount is 2.88 NIS per $\mathrm{CM}^{7}$. The associated loss in the consumer surplus is estimated at $\$ 165$ million per year. This can be seen as roughly the areas A + B in Figure 2. However, only area B constitutes true cost, and this is estimated at $\$ 63$ million. Dividing this figure by the lost 320 million $\mathrm{CM}$, we get $\$ 0.20$ (0.74 NIS) per lost CM.

One argument that must be taken into account in this context is that agriculture creates positive externalities. This is especially true in densely populated Israel in which agriculture plays an important role in preserving limited open spaces. Fleischer and Tsur [61-63] find that agriculture in Israel provides substantial amenity values (equal to roughly one-third of farmers' profits), and even find that for many crops an expansion of cultivated area would be warranted. These studies, however, did not take into consideration negative externalities such as those from water consumption or from pesticide use. Kan et al [64] build on the findings of Fleischer and Tsur, developing a model that allows farmers to choose optimal crops based on amenity value. They find that in a Pareto efficient outcome, amenity values increase slightly, while production value drops slightly, from a profit maximizing situation in which amenity values are not included. The authors take water prices and cultivated land area as determined exogenously, and, because they base their calculations on the amenity values from Fleischer and Tsur (2009), their results also suffer from the same limitations as noted above. Thus, while a very useful study for evaluation of non-crop benefits in Israel, their model results cannot be directly applied in this study.

According to Ayalon et al. [65], the net externalities (positive minus negative) per 0.1 hectare are estimated at $\$ 90$. Through the agricultural water demand function it is estimated that increasing the price of water to 2.88 NIS 


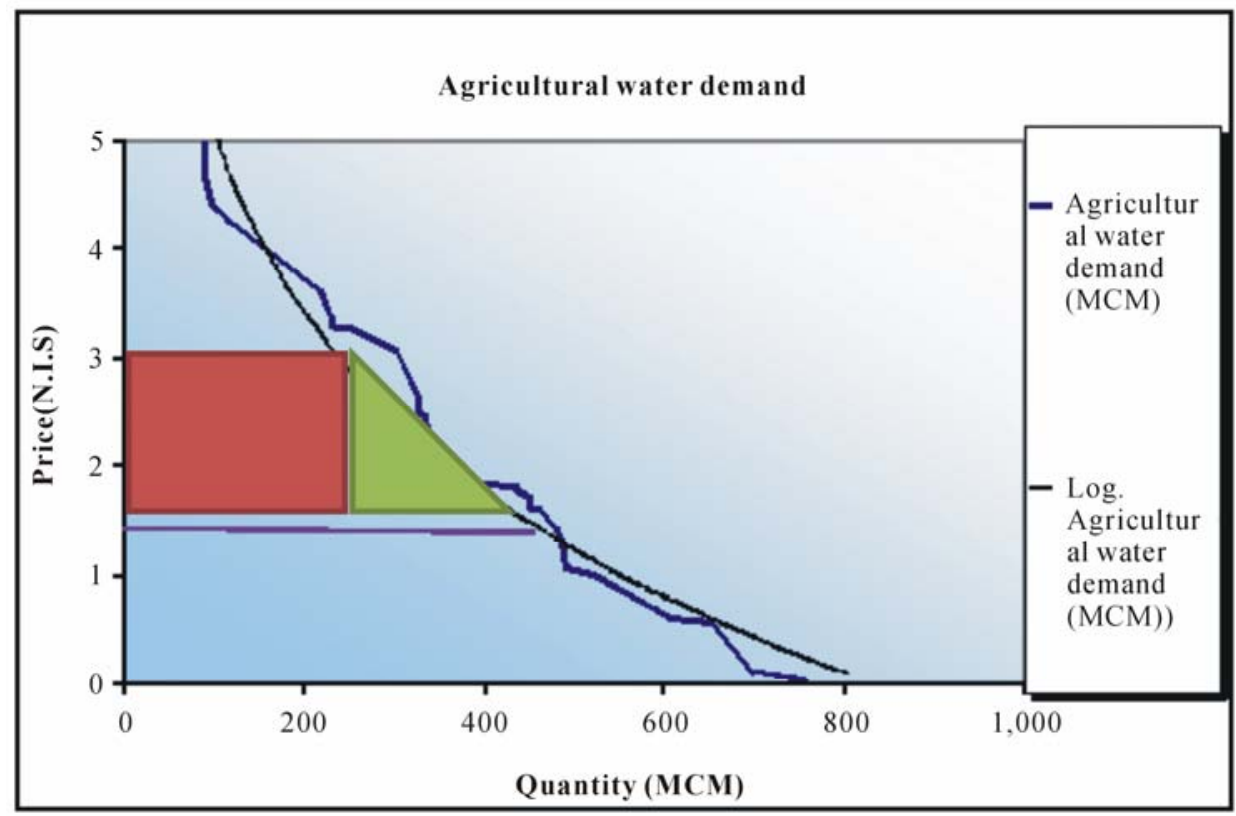

Figure 2. Welfare changes in the agricultural sector due to a price increase.

per CM will take out 10,746 hectares from production (by taking out of production those crops that are no longer viable with the extra price). ${ }^{8}$ The associated external benefit lost with that amount is thus estimated at nearly $\$ 10$ million, corresponding to $\$ 0.03$ (0.11 NIS) per CM. ${ }^{9}$ This brings the total cost of reducing the water available for agricultural use to $\$ 0.23$ (0.85 NIS) per CM, still lower than the cost of desalination (even ignoring the negative externalities of the desalination process).

\subsection{Changing Plant Types and Irrigation}

Irrigation of parks and gardens is responsible for nearly 180 MCM of freshwater consumption annually [66]. In 2001, Israel promulgated statutes designed to improve the use of water in parks and in public and private gardens. Mandated changes included in the statutes included irrigation only in evenings or early morning, replacing irrigation equipment, restrictions based on region, etc.

\footnotetext{
${ }^{7}$ This shift in consumption implies an elasticity of demand of roughly -0.9. Bar Shira et al (2006) calculated a long-term elasticity of -0.46 (and -0.3 in the short run). However, this was using data from 1992-1997, during which prices were lower and allocations higher than at present. It is reasonable to believe that demand has become more inelastic. This might reduce a bit the lost consumer surplus associated with water loss but in order to be on the safe side we will still assume a demand elasticity of -0.9 .

${ }^{8}$ Kan et al. (2009) argue that the impact of water price increase might be a change in crops portfolio. This may reduce to some extent the positive externality of agricultural land. This in turn may reduce somewhat the estimate of 0.23 USD per CM.

${ }^{9}$ This is assuming that all benefits from land not cultivated are lost. This is unlikely, as some amenity values are likely to persist. Thus, this may be an overestimate of the lost benefits from agriculture.
}

The regulations have only been enforced sporadically, however. Moreover, the statutes in question did not address directly the issue of changing the types of plants irrigated. The government published lists of plants that are relatively water-thrifty in 2008 , but did not mandate replacement of water-thirsty plants with water-thrifty ones. The Ministry of Environment estimated that changes in plant types together with changes in irrigation equipment and techniques could save up to $70 \mathrm{MCM}$ annually [66]. FoEME [57] presented figures in which they estimated a one-time $\$ 7500$ cost per dunam to switch from current plants and irrigation techniques to more water-conserving ones. Using a $10 \%$ cost of capital (meant to reflect an upperbound estimate), the report estimated that the cost of switching would be $\$ 0.61$ per $\mathrm{CM}$. Applying this cost to the water savings estimate of the Ministry of Environment gives a savings of 70 MCM annually at a cost of just under \$43 million. This is in contrast to the nearly $\$ 48$ million that desalination would cost.

\subsection{Implementing GreyWater Systems}

Greywater systems, which reuse of water within a household, offer potential water savings for households, reduce the need for sewage transport and treatment, and thereby save the associated direct and environmental costs. Greywater systems, however, would also produce more concentrated sewage, increasing the cost of treatment. In Israel, to date, the Ministry of Health has not approved widespread use of greywater, although there is 
considerable public pressure to do so, including a private Member's bill submitted to Knesset, Israel's parliament.

Household greywater systems require new separate piping, storage facilities, and new building codes, which demand both infrastructure and administrative costs. While some remedial greywater systems use greywater directly for irrigation of yards and gardens, such systems are unlikely to be allowed in Israel, given concerns regarding soil and groundwater contamination. More sophisticated household and commercial greywater treatment units, clearly command higher costs. An analysis by Pareto Engineering [67] estimated that the costs of sophisticated household and commercial greywater systems were over \$2 per CM, well over the cost of desalination even if including the external costs of desalination. Such systems may be economically worthwhile for individual consumers, given that municipal water is often priced at rates of \$2.5 per CM or more, however, it does not appear that greywater systems are an economically efficient option in Israel at this time.

\subsection{Comparing the Alternatives}

A comparative analysis is presented in Table 2. As can be seen in the table, water desalination is the second least efficient of the seven alternatives evaluated, even without taking into account the externalities involved ${ }^{10}$. The analysis found that Israel could save over $700 \mathrm{MCM}$ at costs less than desalination. This is roughly the upper bound of total planned additional desalination capacity. Israel could have reduced the quantity demanded by an amount exceeding current desalination capacity of 280 MCM at less than one third of the cost. This analysis demonstrates that failure to exhaust alternative options is has already been extremely costly. Given that this capacity already exists, however, the proper reference is the
320-780 MCM of future desalination capacity currently being considered.

\section{Summary and Conclusions}

Water shortages are a fact of life in many countries. In semi-arid regions where several alternatives exist to mitigate the problem, a comparative cost-effectiveness analysis is required to allow for economically efficient decision-making. There are two basic approaches to dealing with the problem: supply augmentation and demand reduction. In many places, including Israel, much of the suggested policy measures focus only on the first approach.

In comparing desalination with both alternative supply and demand management options, we have shown that desalination appears to be the second least optimal of all the policy options considered. Israel's choice to pursue desalination before exhausting other more cost efficient options has already cost it tens of millions of dollars in the years since the first desalination plant was approved. Currently, Israel plans to desalinate at least an additional 320 MCM in the immediate term (by 2015), and is considering an additional 150-400 MCM in the medium term (by 2020). The cost of the 320 MCM expansion of capacity is estimated at least $\$ 220$ million, including associated externalities. Since plants designed to desalinate 130 MCM have already been approved, the costs of the remaining $190 \mathrm{MCM}$ of capacity still being considered in the immediate term are estimated at \$130 million. By implementing alternative management options first, Israel could substantially reduce these costs, and could avoid or at least postpone the need for expensive desalination.

Given that five out of six alternative policy options evaluated were found to be more efficient than desalina-

Table 3. Comparative analysis of water-shortage mitigation alternatives.

\begin{tabular}{|c|c|c|c|c|c|c|c|}
\hline & Desalination & $\begin{array}{c}\text { Increased } \\
\text { Wastewater } \\
\text { Treatment }\end{array}$ & $\begin{array}{c}\text { Reduced } \\
\text { Evaporation } \\
\text { from } \\
\text { Reservoirs }\end{array}$ & $\begin{array}{c}\text { Installation } \\
\text { of Water } \\
\text { Savers }\end{array}$ & $\begin{array}{c}\text { Higher Prices } \\
\text { for Water in } \\
\text { Agriculture }\end{array}$ & $\begin{array}{c}\text { Changes in } \\
\text { Park \& } \\
\text { Garden } \\
\text { Plants \& } \\
\text { Irrigation }\end{array}$ & $\begin{array}{c}\text { Advanced } \\
\text { Grey Water } \\
\text { Systems }\end{array}$ \\
\hline $\begin{array}{l}\text { Direct costs } \\
\text { (US\$/CM) }\end{array}$ & 0.52 & 0.45 & 0.01 & 0.45 & 0.20 & 0.61 & $\sim 2.00$ \\
\hline $\begin{array}{l}\text { Total costs } \\
\text { (US\$/CM) }\end{array}$ & 0.585 & 0.45 & ? & 0.45 & 0.23 & 0.61 & $\sim 2.00$ \\
\hline $\begin{array}{c}\text { Total project } \\
\text { costs (million } \\
\text { US\$) }\end{array}$ & 187 & 52 & 0.5 & 85 & 71 & 43 & $\begin{array}{c}\text { Not } \\
\text { calculated }\end{array}$ \\
\hline $\begin{array}{l}\text { Amount of water } \\
\text { saved or added } \\
\text { (MCM/year) }\end{array}$ & 320 & 116 & 37 & 190 & 320 & 70 & 0 \\
\hline
\end{tabular}


tion, even without taking into account the negative environmental externalities of desalination projects, the main conclusion that may be drawn from this study is that expensive supply augmentation options, such as desalination projects, should be implemented only once more cost effective means are exhausted. Climate change is already having a negative impact on water availability in the region [24,68]. Clearly, this aggravates scarcity issues, making the necessity of desalination to meet demand more likely. It does not, however, change the relative ranking of the different alternatives.

Because of the broad scope of this study, it necessarily relied to a large degree on cost estimates from other sources and provided limited detail for each option considered. These are clear limitations of this study. The study was meant to provide a general overview of areas for cost-effective water savings options. It was meant to be illustrative, rather than exhaustive in terms of the number of alternatives considered and the level of detail of cost modeling. A further limitation was that the study did not utilize models that incorporate spatial variation within Israel. Variations in temperature, rainfall, soil quality, and zoning issues between regions within Israel, will dictate the relative cost-efficiencies at a sub-national level [64]. Future research should attempt to incorporate such spatial variation into cost-effectiveness modeling in order to generate a fuller picture of both the total quantities and costs of potential water savings.

Overall, future studies should attempt to quantify in greater detail the external effects of both desalination and agricultural landscape, as these two features will determine the optimal timing of implementation of various water management options, including construction of new desalination plants. Furthermore, estimation of costs of other alternative water management options, including reclamation of contaminated groundwater, rainwater harvesting, and others, would provide an even fuller picture of cost-effective options available to decision-makers.

\section{References}

[1] H. Gvirtzman, "Water Resources in Israel," Yad Ben Tzvi Publishing, Hebrew, 2002.

[2] A. Hurlimann, S. Dolnicar and P. Meye, "Understanding Behavior to Inform Water Supply Management in Developed Nations - A Review of Literature, Conceptual Model and Research Agenda,” Journal of Environmental Management, Vol. 91, No. 1, October 2009, pp. 47-56.

[3] N. Becker, “The Stragedy of Water,” Water Engineering, Vol. 76, 2001, pp. 15-19.

[4] Y. Dreizin, “Ashkelon Seawater Desalination ProjectOff-Taker's Self Costs, Supplied Water Costs, Total Costs and Benefits,” Desalination, Vol. 190, No.1-3, 2006, pp. 104-120.
[5] Y. Dreizin, A. Tenne and D. Hoffman, "Integrating Large Scale Seawater Desalination Plants within Israel's Water Supply System” Desalination, Vol. 220, No.1-3, pp. 132149.

[6] R. Sanders, "Water Desalting and the Middle East Peace Process,” Technology in Society, Vol. 31, No. 1, February 2009, pp. 94-99.

[7] A. Tal, "Seeking Sustainability: Israel's Evolving Water Management Strategy,” Science, Vol. 313, No. 5790, August 2006, pp. 1081-1084.

[8] S. Dolnicar and A. I. Schafer, "Desalinated versus Recycled Water: Public Perceptions and Profiles of the Accepters," Journal of Environmental Management, Vol. 90, No. 2, February 2009, pp. 888-900.

[9] M. El-Fadel and I. Alameddine, "Desalination in Arid Regions: Merits and Concerns,” Journal of Water Supply Research and Technology-Aqua, Vol. 54, No. 7, November 2005, pp. 449-461.

[10] E. Yuhas and T. Daniels, "The US Freshwater Supply Shortage: Experiences with Desalination as Part of the Solution" Journal of Environmental Planning and Management, Vol. 49, No. 4, July 2009, pp. 571-585.

[11] I. C. Karagiannis and P. G. Soldatos, "Water Desalination Cost Literature: Review and Assessment," Desalination, Vol. 223, No.1-3, 2008, pp. 448-456.

[12] K. Reddy and N. Ghaffour, "Overview of the Cost of Desalinated Water and Costing Methodologies,” Desalination, Vol. 207, No. 1-3, 2005, pp. 340-353.

[13] K. V. Reddy, "Review and Evaluation of Desalination Cost and Costing Methodologies," International Journal of Nuclear Desalination, Vol. 3, No. 1, 2008, pp. 79-94.

[14] Y. Zhou and R. S. J. Tol "Evaluating the Costs of Desalination and Water Transport," Water Resources Research, Vol. 41, No. 1-10, W03003, 2005, pp. 269-287.

[15] P. Glueckstern and M. Priel, "Advanced Concept of Large Seawater Desalination Systems for Israel," Desalination, Vol. 119, No.1-3, 1998, pp.33-45.

[16] G. W. Characklis, R. C. Griffin and P. B. Bedient, "Measuring the Long-Term Regional Benefits of Salinity Reduction," Journal of Agricultural and Resource Economics, Vol. 30, No. 1, 2005, pp. 69-93.

[17] A. M. Altayaran and I. M. Madany, "Impact of a Desalination Plant on the Physical and Chemical-Properties of the Seawater, Bahrain,” Water Research, Vol. 26, No. 4, April 1992, pp. 435-441.

[18] P. K. Azis, A. I. Al-Tisan, M. Al-Daili, T. N. Green, A. G. I. Dalvi and M. A. Javeed, "Effects of Environment on Source Water for Desalination Plants on the Eastern Coast of Saudi Arabia,” Desalination, Vol. 132, No. 1-3, 2000, pp. 29-40.

[19] R. Einav, K. Harussi and D. Perry, “The Footprints of Desalination Processes on the Environment," Irrigation and Water Engineering, Vol. 17, 2002, pp. 19-28.

[20] N. Becker and D. Lavee, "The Effect and Reform of Water Pricing: The Israeli Experience,” International Journal of Water Resource Development, Vol. 18, No. 2, June 
2002, pp. 353-366.

[21] I. Fischhendler, "Institutional Conditions for IWRM: The Israeli Case,” Ground Water, Vol. 46, No. 1, January-February 2008, pp. 91-102.

[22] Y. Margoninsky, "Macroeconomic and Institutional Sources of Environmental Changes - The Case of Israel's Water Sector," Water Policy, Vol. 11, No. 3, 2009, pp. 307-319.

[23] A. Kartin, "Factors Inhibiting Structural Changes in Israel's Water Policy,” Political Geography, Vol. 19, No. 1, January 2000, pp. 97-115.

[24] P. Alpert, S. O. Krichak, H. Shafir, D. Haim and I. Osetinsky, "Climatic Trends to Extremes Employing Regional Modeling and Statistical Interpretation over the E. Mediterranean,” Global and Planetary Change, Vol. 63, No. 2-3, September 2008, pp. 163-170.

[25] R. Hovel, "The Tax did What He was Supposed to do: Water Consumption Decreased by $20 \%$ in 2009," Calcalist, Vol. 19, January, 2010.

[26] Z. Lavi, "In the Knesset, Support for Continuing the Freeze on Drought Tax", Ynet News Service, Vol. 8, March 2010. (In Hebrew)

http://www.ynet.co.il/articles/0,7340,L-3859529,00.html

[27] State Comptroller Report, "The National Committee of Inquiry Regarding the Management of the Water Economy in Israel”, 2009.

[28] T. Schorr, Speech Given at Conference on "Reuse of Grey Water: From Theory to Practice,” Ramat Gan, Israel, April 2010.

[29] T. Rinat, "Minister Erdan Criticizes Water Authority Campaign: Calling for Conservation for Three Years Only”, Haaretz, 22 July 2010. (In Hebrew)

[30] J. Rothfeder, “Every Drop for Sale,” Tarcher/Penguin, 2004.

[31] T. Daniels and K. Daniels, "The Environmental Planning Handbook for Sustainable Communities and Regions,” APA/Planners Press, 2003.

[32] C. Sabol, Testimony to the House Subcommittee on Water and Power, 24 May 2005. http://resourcescommittee.house.gov/archives/109/testim ony/2005/colinsabol.pdf (accessed 21 October 2008).

[33] W. Alley, "Desalination of Ground Water: Earth Science Perspectives,” USGS Fact Sheet 075-03. http://pubs.usgs.gov.

[34] T. Levin, “Turning Oceans into Tap Water," On Earth, Vol. 26, Summer 2004, pp. 28-33.

[35] G. Pitzer, "Tapping the World's Largest Reservoir: Desalination," Western Water, January-February 2003, pp. 4-13.

[36] National Research Council, "Desalination: A National Perspective," Committee on Advancing Desalination Technology, National Research Council, 2008.

[37] N. H. Afgan, M. Darwish and M. G. Carvalho, "Sustainability Assessement of Desalination Plants for Water Production,” Desalination, Vol. 124, No. 1-3, 1999, pp. 19-31.
[38] S. R. Downward and R. Taylor, “An Assessment of Spain's Programa AGUA and Its Implications for Sustainable Water Management in the Province of Almeria, Southeast Spain,” Journal of Environmental Management, Vol. 82, No. 2, January 2007, pp. 277-289.

[39] Y. Tsur and A. Zemel, "R\&D Policies for Desalination Technologies,” Agricultural Economics, Vol. 24, No. 1, December 2000, pp. 73-85.

[40] M. Sadiq, "Metal Contamination in Sediments from a Desalination Plant Effluent Outfall Area," Science of the Total Environment, Vol. 287, No. 1-2, March 2002, pp. 37-44.

[41] E. P. Glenn, "Cienega de Santa Clara: Endangered Wetland in the Colorado River Delta, Sonora, Mexico," Natural Resources Journal, Vol. 32, 1992, pp. 817-824.

[42] J. R. Stokes and A. Horvath, "Energy and Air Emission Effects of Water Supply," Environmental Science \& Technology, Vol. 43, No. 8, April 2009, pp. 2680-2687.

[43] S. Nisan and N. Benzarti, “A Comprehensive Economic Evaluation of Integrated Desalination Systems Using Fossil Fuelled and Nuclear Energies and Including Their Environmental Costs,” Desalination, Vol. 229, No. 1, September 2008, pp. 125-146.

[44] I. C. Karagiann and P. G. Soldatos, "Estimation of Critical CO2 Values When Planning the Power Source in Water Desalination: The Case of the Small Aegean Islands,” Energy Policy, Vol. 38, No. 8 August 2010, pp. 3891- 3897.

[45] R. Samit, “The Future of Desalination in Israel,” Irrigation and Water Engineering, Vol. 12, 2001, pp. 45-49.

[46] Ministry of Environment (Israel), External Costs Of Air Pollution from Energy Production-Final Report, September 2008. (In Hebrew)

[47] European Commission, Valuing External Costs from Energy Production and Transportation. http://www.ext erne.info

[48] Israeli Electric Company (IEC), http://www.iec.co.il/

[49] Kivun LTD, "Guidelines for Shore Taxes Due to Externalities," Report submitted to the Ministry of Environment, Jerusalem, Israel. 2006. (In Hebrew)

[50] H. Winters, I. R. Isquith and R. Bakish. "Influence of Desalination Effluents on Marine Ecosystems”, Desalination, Vol. 30, 1979, pp. 403-410.

[51] R. Einav, K. Harussi, and D. Perry. "The Footprint of the Desalination Processes on the Environment,” Desalination Vol. 152, No. 1, 2003, pp. 141-154.

[52] S. Lattemann, and T. Höpner, "Environmental Impact and Impact Assessment of Seawater Desalination,” Desalination, Vol. 220, No. 1, 2008, pp. 1-15.

[53] UNEP, Desalination Resource and Guidance Manual for Environmental Impact Assessments, United Nations Environment Programme, Regional Office for West Asia, Manama, and World Health Organization, Regional Office for the Eastern Mediterranean, Cairo, 2008.

[54] D. Roberts, A. David, L. Emma, L. Johnston and N. A. Knott, "Impacts of Desalination Plant Discharges on the 
Marine Environment: A Critical Review of Published studies," Water Research, Vol. 44, No. 18, 2010, pp. 5117-5128.

[55] I. Safrai and A. Zask. "Reverse Osmosis Desalination Plants-Marine Environmentalist Regulator Point of View”. Desalination, Vol. 220, No. 1, 2008, pp. 72-84.

[56] D. Lavee, "Cost-Benefit Analysis of Alternative Wastewater Treatment Standards: A Case Study in Israel,” Water and Environment Journal. (Forthcoming).

[57] Friends of the Earth-Middle East (FoEME), “An Economic Analysis of Policy Options for Water Conservation in Israel,” July 2010. http://www.foeme.org/

[58] P. Dar, “The Efficiency of Reduced Water Consumption in the Household Sector," The Center for Environmental Policy at the Jerusalem Institute, Discussion paper 30, 2002. (In Hebrew)

[59] Y. Darel, "With Water-Savers We could have Saved Half of the Sea of Galilee”, Ynet News Service, 9 May, 2010. http://www.ynet.co.il/articles/0,7340,L-3886750,00.html.

[60] Z. Bar-Shira, I. Finkelshtain and A. Simhon, "BlockRate versus Uniform Water Pricing in Agriculture: An Empirical Analysis,” American Journal of Agricultural Economics, Vol. 88, No. 4, 2006, pp. 986-999.

[61] A. Fleischer and Y. Tsur, "Measuring the Recreational Value of Agricultural Landscape," European Review of Agricultural Economics, Vol. 27, No. 3, 2000, pp. 385398.
[62] A. Fleischer and Y. Tsur, "Measuring the Economic Value of Open Space," Journal of Agricultural Economics, Vol. 54, No. 2, 2003, pp. 269-283.

[63] A. Fleischer and Y. Tsur, "The Amenity Value of Agricultural Landscape and Rural-Urban Land Allocation," Journal of Agricultural Economics, Vol. 60, No. 1, 2009, pp. 132-153.

[64] I. Kan, D. Haim, M. Rapaport-Rom and M. Shechter, "Environmental Amenities and Optimal Agricultural Land Use: The Case of Israel,” Ecological Economics, Vol. 68, No. 6, 2009, pp. 1893-1898.

[65] O. Ayalon, H. Tzaban, Y. Avnimelech, L. Amdor, and N. Feler, "Sustainable Agriculture: How to Internalize Externalities in the Farming Sector?" Shmuel Neeman Institute at the Technion University, Haifa, Israel, 2004. (In Hebrew).

[66] Ministry of Environmental Protection (Israel), “Tackling Israel's Water Crisis,” Israel Environment Bulletin, Vol. 35 (September), 2009, pp. 12-17.

[67] Pareto Engineering, "A Cost Benefit Analysis of Grey Water Reuse Projects in Israel,” 24 May 2007. http://www.sviva.gov.il/Enviroment/Static/Binaries/index _pirsumim/p0495_1.pdf

[68] I. Kan, M. Rapaport-Rom and M. Shechter, “Assessing Climate Change Impacts on Water, Land-Use and Economic Return in Agriculture.” http://ssrn.com/abstract=1020562 